Brandeis | иввая

brandeis.edu/j-caste
CASTE: A Global Journal on Social Exclusion

Vol. 2 No. 2 pp. $219-234$

October-November 2021

ISSN 2639-4928

https://doi.org/10.26812/caste.v2i2.337

\title{
A Commentary on Ambedkar's Posthumously Published "Philosophy of Hinduism" - Part III'
}

\author{
Rajesh Sampath'
}

\section{Abstract}

This article forms part III of a running commentary on Ambedkar's posthumously published "Philosophy of History" (Ambedkar, 2014a). We attempt to follow Ambedkar's reflections on the early origins of religion and his initial distinctions of the religions of "savage society" and "civilized society" (Ambedkar, 2014a, p. 9). Using the tools of philosophical critique, we see his attempt to dissect the real "principal" (Ambedkar, 20I4a, p. I0) of religion beyond the apparitional nature of rites, rituals, and taboos. This leads to a series of deductions of what constitutes the very "core," "source," and "substance" of religion rooted in the "preservation of life" (Ambedkar, $2014 a$, p. 10). However, this is also a moment that will foreshadow Ambedkar's ultimate judgement of Hinduism's status as a religion when founded on the unequal social structure of caste. We argue the following in this article: what Ambedkar says about the architectonic of "savage society" and the failure to undergo a profound revolution in the nature and concept of religion bears an eerie resemblance to what ultimately takes the place of "savage society" (Ambedkar, 2014a, p. 9) over time, namely the Hindu caste system. This makes modern Hinduism a strange hybrid of pre-history and a future history whose conclusion is uncertain. Whether caste can disappear from society is the burning question. And this is intertwined with profound metaphysical

\footnotetext{
'Associate Professor of the Philosophy of Justice, Rights, and Social Change

The Heller School for Social Policy and Management

Brandeis University, Waltham, MA, USA

E-mail: rsampath@brandeis.edu
}

${ }^{1}$ This article is dedicated to the memory of the pioneering scholar on caste and untouchability, Gail Omvedt. She passed away on August $24^{\text {th }}, 2021$ in her village, Kasegaon Sangli, Maharashtra, the state where Ambedkar was born. Retrieved from: https://thewire.in/ society/india-will-remember-gail-omvedt-forever 
questions of time, life, birth, and death, which only philosophy can deconstruct if a religion, like Hinduism, were submitted for critical judgement. The article concludes with an attempt to set the stage for the next phase of the commentary: there Ambedkar will transition from a general discussion about the philosophy and history of religion as a concept to an actual engagement with the philosophical contents of the religion known and practiced by hundreds of millions of adherents as Hinduism. As we already know, his conclusion is dire: a religion can only be true if it is rooted in 'justice' and serves the 'utility' of individual freedom (Ambedkar, $2014 a$, p. 22).

\section{Introduction}

In Part II of our Commentary on Ambedkar's posthumously published "Philosophy of Hinduism" 2 we left off on the issue of a massive epochal shift in the philosophy of history: one that involves a rearrangement of fundamental relations of society, God, and man (human). At the core of Ambedkar's conviction is the need for new theoretical concepts to understand the nature and process of revolutionary change. To recall, Ambedkar is dealing with the revolution in the philosophical conception of religion (Ambedkar 2014a, p. 9), and not a particular historical event, text, or person upon which a religion is founded. Ultimately his goal is to achieve the practical realization of radical revolution and recreation of society. The stakes are so high. Even a decolonial achievement of creating a modern, constitutional, secular, and legal democratic constitution was not sufficient in trying to achieve actual equality and liberty. We must make a phenomenological distinction between revolutions in philosophical concepts of religion and historical events of revolutionary change in either philosophy (say from one great thinker to another like Kant to Hegel) or religion (say the creation of a religion hatching out of another, for example gentile Christianity emerging out of first century CE Palestinian Judaism under Roman rule). Throughout this commentary, we have asserted the necessity of a genuinely philosophical investigation into the practical possibility of reimagining Indian society without the caste system. These notorious divisions of laborers within classes (as opposed to a mere economic division of classes) engineers a social system aimed at perfecting degradation and indignity. Matter of fact, the animus of the whole system is based on antipathy for the other. The problem for Ambedkar is why and how this system descended from Hinduism, in particular, and nowhere else in world history.

\section{Main Text}

Let us pick up where we left off in Ambedkar's text. At the foundation of his thought, Ambedkar is concerned with the notion of how religion and society became fused to the point of no return: this is the moment which yields a certain social structure of generalized behavior that goes unquestioned, namely the stringent caste system. If in other contexts, secularism replaces metaphysical-religious cosmology as the basis of the legal, political, economic, and cultural structures of a society, as it happened in the

\footnotetext{
${ }^{2}$ The First Edition was published by the Education Department, Govt. of Maharashtra: 14 April, 1987. See Dr. Babasaheb Ambedkar: Writings and Speeches, Vol. 3, ed. Hari Narake, 2nd Edition (New Delhi: Dr. Ambedkar Foundations, 2014).
} 
late eighteenth century West, particularly the French Enlightenment and the French and American democratic revolutions, the question then becomes why religious hierarchies continue to persist in secular, liberal, pluralistic democracies. In principal, democracies valorize individual equality and liberty above all else. This constitutes the ultimate paradox: namely the persistence of religious hierarchy and Hindu caste as hierarchies within a hierarchy in a postcolonial Global South democratic state like today's India. Democratic states are by nature non-hierarchical and ensure separations of power to decentralize any chance for tyranny or fascism to take root. The rule of law is paramount, and individual rights sacrosanct. But in the Indian context past and present, the notion of an individual is an illusion.

In other words, it is not enough to say secularism merely replaces religion; it is not sufficient to say that there is a change in principle of organizing society (say secularism instead of theocracy), for there must be change in substance too. Secularism is the substitute for the religious gluing of elements to compose a hierarchic society and the political-economic legal anatomy of its differentiated body of inequality; yet it is limited. Religions, which for the most part continue due to the enduring mystery of the origin of life itself and the fact of ceaseless human mortality and death, is not the pure object of philosophical study. Some religions, like Western Roman Catholicism, require hierarchy to maintain ownership of the cumulative body of knowledge descending from heritage: the purpose is to ensure that adherents maintain their duty to obey certain principles and rituals on a chronological calendar. However, the religious hierarchy fused with social hierarchy is something else, particularly in the Eastern context where democracies were born after decolonization. Instead, Ambedkar is attempting to articulate yet another revolution that is necessary, one that has not taken place thus far in his early to mid-twentieth century South Asian historical context, even after decolonization and the birth of legal, constitutional, secular democracy. And it is one that remains suspended even in our day.

After introducing the forces of traditional secularism brought on by scientific revolutions (Newton's and Darwin's as the most influential) and science (and industrial technology) shaping modern knowledge in general, Ambedkar turns to another revolution which must be critically examined (Ambedkar, 2014a, p. 9). One plane of world history is the movement of religion as the dominant horizon that shapes all reality to the 'modern' age of science and secularism. But for Ambedkar, we need to inquire about another level of history that is not so visible: there in its murky realm from the depths of a unique, non-Western philosophical imagination an interesting theoretical conceptual critique emerges. It is to this critique that we will devote this section of our commentary. Through Ambedkar's text, one discovers the absence of a revolutionary change in the very conception of religion itself irrespective of the grand transition of religion in general to secularism; such transitions can be taken for granted in say contemporary Western European liberal democracies where majority atheist populations now exist. Perhaps in some histories and civilizations the shift in the concept of religion took place, but in others it has failed to materialize. He states:

this Revolution is so great and so immense that it has brought about a complete transformation in the nature of Religion as it is taken to be by savage society and by civilized society although very few seem to be aware of it (Ambedkar, 2014a, p. 9). 
The question again is one of revolution and the nature of transformation itself, not just the transformation of the nature of something, in this case religion. Prior to the transition from religion to secularism is an internal transition within the conceptual structure of religion itself - namely the movement from "savage society" to "civilized society" (Ambedkar, 2014a, p. 10). Truly the a priori dimension in a philosophy of historical changes of epochs-like religion to secularism-has in a non-circular way its basis in a fundamental transformation of the nature of society. Society is the ontological foundation by which there can be any history, even though one thinks of society as something atemporal or ahistorical.

Ambedkar is not making a simple statement about an empirical fact of how historical reality changed at some juncture, for example an important event like the French Revolution. Rather, he is unfolding a philosophical-history of how religion altered its fundamental nature through a change in the essence of society and hence a change embedded within a change: this realm exists at a deeper level of historical time beyond the historical empirical contents of religions and their epochal shifts. For example, one could describe how early Christianity arose after the first century CE context, post-Roman destruction of the Second Temple period of the ancient Jewish context, with the first Gospels written by Jews who lived around the Mediterranean and what is modern Egypt and Turkey and St. Paul's far-flung journeys and letters; but then over centuries it developed into the modern institutional structure of Christianity today, for example Roman Catholicism, which is upheld by the Vatican's universal jurisprudence. Modern and ancient Christianity seem worlds apart even though the religious proclamation of faith is one rooted in historical continuity given the papal lineage that descends from the living disciple of Jesus, namely St. Peter. ${ }^{3}$ There, history and divine revelation are intertwined. But that pertains to a specific history of a specific religion. Instead, Ambedkar, one can say, is interested in a philosophy of a general historical transmutation in the conception of religion itself. How philosophy, history, and religion come into mutual encounter with one another is of the utmost urgency with regard to discovering a principle of justice to enact radical social change. This seems to pulsate throughout Ambedkar's incomplete manuscript.

Taking his earlier statement on how the "Revolution touches the nature and content of ruling conceptions of relations of God to man, Society to man and of man to man" (Ambedkar, 2014a, p. 9), which we analyzed in part II of our commentary, we can now go deeper with Ambedkar's description of the essential features of social structures. The key focus of this section of our critical analysis will be on vital questions of the philosophical change in religion. We have to get at the heart of the issues of historical temporality and movement in the mutation from "savage society" to "civilized society" (Ambedkar, 2014a, p. 9). Ambedkar offers interesting definitions of both types of society, however preliminary they may appear in his text. They are certainly ripe for further distillation given the legacy of his profound thought.

The variation of relations (God to human, society to human and human to human) is itself enfolded in a deeper event of metamorphosis from 'savage' to 'civilized' (Ambedkar, 2014a, p. 10); but as long as caste persists in today's Indian modernity, then one can say there are mechanisms by which the failure of this revolution is reproduced, thus maintaining an indefatigable status quo. One can make a distinction between a top-

${ }^{3}$ See the formidable volumes by Anglican theologian N.T. Wright- The New Testament and the People of God (1992), Jesus and the Victory of God (1996), and The Resurrection of the Son of God (2003) published by Fortress Press. 
down political grip on society, like a dictatorship, and the naturally or organically selfreproducing system of microscopic powers that reproduce the same behavior from one generation to the next. If dictatorship is like a vice that traps something and squeezes, caste is like a pinball machine with one entrance (birth) and one exit or loss (death). We must inquire into these mechanisms that reproduce the status quo, and in that regard Ambedkar gives us the tools to further shape certain parameters to distinguish between the 'savage' and the 'civilized' (Ambedkar, 2014a, p. 10). ${ }^{4}$

When it comes to 'savage' (Ambedkar, 2014a, p. 10) society, Ambedkar notes several important aspects. Although many Western anthropologists, such as LéviStrauss, throughout the twentieth century would take note of the phenomena of totem and caste, let alone their distinctions, Ambedkar gives us two primary elements (Ambedkar, 2014a, p. 10) that compose this type of Eastern social formation. He speaks from an Eastern mind, not that of a Western-raised anthropologist. We must put aside any immediate intuitions of 'savage' as something 'backward' or 'underdeveloped." First is the linkage between "the practice of magic or tabu" and "the worship of fetish and totem" (Ambedkar, 2014a, p. 10). ${ }^{6}$ These are not terms that can be easily collapsed

${ }^{4} \mathrm{~A}$ separate work, mentioned in part II of commentary, would be an unrelenting engagement with Lévi-Strauss's structuralist attempts to compare, without collapsing, different systems such as 'totem' and 'caste.' His magisterial works, Totemism (1962) and The Savage Mind (1964), are ripe for appropriation while reading Ambedkar's entire corpus, particularly his most theoretically inventive ones.

${ }^{5}$ This could take us straight into debates about Marxist critiques of development, Latin American theories of development and underdevelopment, and Wallerstein's world-systems analysis. Those would be critical investigations if one were interested in the pitfalls of capitalist politicaleconomy and the tenacity of caste as social inequality. But political-economic analysis would have to follow a prior analysis of social revolution as Ambedkar says in Annihilation of Caste (Ambedkar, 2014b).

'It would be tempting to dive into Marx's conception of the "the fetishism of commodities" at this point even though he is critiquing the modern form of capitalism and labor exploitation. We could transfer his definitions and telescope what he says about commodities to the creation of casted bodies in Hindu metaphysics. On the 'fetish' Marx says: "A commodity is therefore a mysterious thing, simply because in it the social character of men's labour appears to them as an objective character stamped upon the product of that labour; because the relation of the producers to the sum total of their own labour is presented to them as a social relation, existing not between themselves, but between the products of their labour. This is the reason why the products of labour become commodities, social things whose qualities are at the same time perceptible and imperceptible by the senses. In the same way the light from an object is perceived by us not as the subjective excitation of our optic nerve, but as the objective form of something outside the eye itself. But, in the act of seeing, there is at all events, an actual passage of light from one thing to another, from the external object to the eye. There is a physical relation between physical things. But it is different with commodities. There, the existence of the things quâ commodities, and the value relation between the products of labour which stamps them as commodities, have absolutely no connection with their physical properties and with the material relations arising therefrom. There it is a definite social relation between men, that assumes, in their eyes, the fantastic form of a relation between things. In order, therefore, to find an analogy, we must have recourse to the mist-enveloped regions of the religious world. In that world the productions of the human brain appear as independent beings endowed with life, and entering into relation both with one another and the human race. So it is in the world of commodities with the products of men's hands. This I call the Fetishism which attaches itself to the products of labour, so soon as they are produced as commodities, and which is therefore inseparable from the production of commodities. 
into one another, for example in an anthropology of Indian culture from Vedic antiquity to the present. So we must bracket what these relations mean, particularly the relation between 'practice' and 'worship' (Ambedkar, 2014a, p. 10) within a generalized system of oppression. Worshiping deities or practicing rituals is one thing; but if the animation or vital force within worship and practice is designed to enforce indignity and inequality, then we need a genealogical investigation into the causes of how a system has come about, it's dispersed causes and roots. For these forces are not seen in the self-justification for the particular kind of worship and practice.

Such a system governs the dynamics of everyday life down to the tiniest details, for example who gets to draw water from the well or who gets to walk in certain spaces with their shoes (as opposed to being forced to take them off as a sign of submission); the complexity of the manifestation of details are infinitely differentiated making them barely perceptible to the outsider's eye. The exteriorization of humiliation is something that remains invisible to the outsider, but internally an object of constant anxiety and pain in the internal consciousness of the oppressed. The invisible and the visible switch places so that nothing appears to be happening. Ambedkar's thought will help us develop new ideas on these relations later in this section of the text.

The other aspect involves how "rights, ceremonies, magic, tabu, totem and fetish" become apparent in "their connection with certain occasions" (Ambedkar, 2014a, p. 10). Such events in life's journey center on the "crises of human life," which include "birth, the birth of the first born, attaining manhood, reaching puberty, marriage, sickness, death and war" (Ambedkar, 2014a, p. 10). All these do not occur in a vacuum, but are "marked out for the performance of rites and ceremonies, the use of magic and worship of the totem" (Ambedkar, 2014a, p. 10). The event of reproduction is not just climacteric for dynastic cycles of power and the reproduction of labor for ceaseless exploitation in any economy, not just capitalist ones. It is paramount for ritualistic reasons that reinforce the hierarchies of identity that are prohibitive for true individuality to develop. Furthermore, birth is central one can say, but also birth of the first-born son given the nature of patriarchy in a son-preference culture. ${ }^{7}$ Birth goes beyond the mere biological propagation of the species; it is highly guarded, almost predestined in its embryonic stage, so that the whole social structure is guaranteed protection from any external threats. Patriarchy, masculinity, Hindu caste are in fact aligned at their very core.

This Fetishism of commodities has its origin, as the foregoing analysis has already shown, in the peculiar social character of the labour that produces them " (Marx, 2015, pp. 47-48). Retrieved from: https://www.marxists.org/archive/marx/works/download/pdf/CapitalVolume-I.pdf. Although Marx is introducing a supersensory notion of how commodities become a unique object of uncontrollable desire, while occluding the labor process that is exploited in their creation, he links his idea of the "fetish' to the "fantastic" and "mist-enveloped regions of the religious world" (Marx, 2015, p. 48). With Ambedkar's critique of caste, which too involves the sadistic dimension attached to labor as differentiated, one has to go a step further in terms of the fetish of caste itself or the separation of human beings as metaphysical entities marking out transitions of birth, death, and rebirth. The nature of the task even as duty for the sake of duty in a specialized labor of a certain caste member is inconsequential; the reality of its oppressive nature is not. This is something, obviously, Marx could not penetrate in his Western European context. We would have to re-read these precious sections in Marx's Capital volumes again with the unrelenting will to deconstruct caste with new terms and concepts.

${ }^{7}$ See Martha Nussbaum, Women and Human Development (Cambridge: Cambridge University Press, 2000). 
We will pause here because the interesting thing to notice is that all of these life events are constituted as a "crisis." That means at their ontological level there are conditions by which these events cause an impenetrable anxiety (not simply a psychological one), which will turn out to be the problem of the temporality and movement of karmic cycles and reincarnation. ${ }^{8}$ The act of birth for example is so shocking, not because it marks the joyous occasion or miracle of welcoming new life into the world; but the dark secret of passage from something that has died into a new body. Although the newborn may not be forsaken by being aborted or committed to infanticide (except for example with the atrocious gender preference for male rather than female babies), it becomes a living object of mourning stripped of autonomous dignity and the fullness of life. The more impure, the more death is inscribed in birth. Desecration and waste must be guarded against, not just through sacred rituals but abjection of living human beings. That is just one example, others being the event of death and cremation, or rites of passages into adulthood with its masculinist and patriarchal overtones since men can only attain to Brahmin priesthood. But for sure they need to be differentiated from any empirical or concrete specific notion of 'crisis,' for example a difficult pregnancy or even miscarriage; in fact that would be the embodiment of death in a birth that did not happen, an entirely different matter.

Rather, this question of 'crisis' at the most general level regards a fundamental anxiety that the system of caste tries to contain in the tightest of strictures around human relations, associations, and contact given the distinction between purity and impurity. The tighter the bonds at the most minute levels, the more the system preserves itself and actually grows stronger over time. Purity and impurity relate to a long, complex theological heritage, which itself interrelates birth, death, and rebirth, the nature of creation and time, and the idea of the divine, particularly the unity of Self (Atman) and the Absolute (Brahman). Such a self-proclaimed ancestry dates back as far as the Upanishads, which followed the Vedic age, over two millennia ago. ${ }^{9}$ However, Ambedkar will attempt to discover a deeper basis in the philosophy and history of the religion of Hinduism to see what gives rises to this macabre theological content. This is tantamount to articulating a new philosophy by way of critique and deconstruction that can explain the possible origins of how Hindu metaphysical concepts came about and started to congeal into one another and into intricate interrelations. Obviously this borders on speculative thought with a genealogical tinge because the aim is not to offer empirical proof by way of ancient history, archaeology, and physical anthropology on actual cause-effect relations. The purpose is not to establish historical facts.

Let us try to develop some further propositions. What is 'savage' (Ambedkar, 2014a, p. 10) is not merely a stage in chronological historical time: one that is in the distant, physically measurable, datable past, say $3000 \mathrm{BCE}$; one that could be

\footnotetext{
${ }^{8}$ We repeated several times the unavoidable need to read Heidegger's Being and Time (1927) as a new contribution to the philosophical critiques of caste in Ambedkarite studies. This is particularly important when Heidegger discusses 'anxiety/dread/malaise/uneasiness,' 'care and concern,' and the authentic approach towards death as a possibility for orienting one's life (Heidegger, 1962, p. 227). Of course Heidegger was responding to the Judeo-Christian tradition, particularly the Catholic-medieval underpinnings of Western metaphysics of the conscience and the soul, and certainly not Hindu dogmas on sin, death, transmigration, and reincarnation. That would take us into an entirely other realm, which is not and could not be articulated by Heidegger.
}

${ }^{9}$ See Wendy Doniger, The Hindus: An Alternative History (New York: Penguin, 2010). 
discovered through the work of physical anthropology and archaeology, for example through carbon dating. It is by no means reducible to a simple relation between present and past, or even the remnant or trace of the past in the present, the past living on in and as the present, not just a legacy. ${ }^{10}$ Rather, the question here is that Ambedkar names the 'savage' as a certain concept of religion, not a pre-religious or pre-historic notion before the birth of canonical world religions that are extant, for example Judaism, Islam, Christianity, Confucianism, and Buddhism. Those religions center single nonhistorical (depending on who you ask) and historical human beings and texts attributed to them- Moses, Buddha, Confucius, Jesus, and the Prophet Mohammed. (In the case of one of them, an actual historical person is equated with the Godhead during His lifetime and certainly after his death and allegedly witnessed bodily resurrection.) However, the linkage between the 'practice of magic or tabu' and the 'worship of fetish and totem' (Ambedkar, 2014a, p. 10) is the material actualization of supersensory notions surrounding birth and death in stratified and segmented hierarchies of bodies in space. Perhaps the events of birth (which seem internal to a womb) and event of death (as the passage of a possible soul out of a body and the world) are in fact externalized and repeated in the microscopic acts of alleged signification in a ritual or incantation. This may sound strange, but the phenomenological critique requires it as a possibility for explanation. Birth, death, and rebirth are actual objects in the world, an externalized and material immanence of the most transcendental metaphysical mysteries; typically the latter are invisible and non-physical like a concept of the 'soul.' However, things are different in this Eastern context. Taking a mere condescending attitude from say a modern secular and scientific gaze of some 'primitive' prehistorical past will not help the critical endeavor to dismantle caste today. We have to go inside the system and get to the roots in order to pull them out of the ground.

Here, once again, Ambedkar makes a critical distinction between the actual "origin," "source," and "substance" of religion to what is merely "incidental" rather than its "principal" (Ambedkar, 2014a, p. 10). We will quote the full passage here:

The principal thing in the Religion of the savage are the elemental facts of human existence such as life, death, birth, marriage etc. Magic, tabu, totem are things which are incidental. Magic, tabu, totem, fetish etc., are not the ends. They are only the means. The end is life and the preservation of life. Magic, tabu etc., are resorted to by the savage society not for their own sake but to conserve life and to exercise evil influences from doing harm to life. Thus understood the religion of the savage society was concerned with life and the preservation of life and it is these life processes which constitute the substance and source of the religion of the savage society. So great was the concern of the savage society for life and the preservation of life that it made them the basis of its religion. So central were the life processes in the religion of the savage society that everything which affected them became part of its religion. The ceremonies of the savage society were not only concerned with the events of birth, attaining of manhood, puberty, marriage, sickness, death and war they were also concerned with food (Ambedkar, 2014a, p. 10).

${ }^{10}$ Heidegger is important here too, particularly his chapter on 'temporality and historicality' in Division Two of Being and Time (Heidegger, 1962, pp. 424-427). 
The process of life and its preservation form the main purpose. Life and preservation of life is the core and centre of the Religion of the savage society (Ambedkar, 2014a, p. 10).

Let us draw some more distinctions. There is much to glean from these crucial passages based on what we quoted earlier: differentiating the 'origin,' 'source,' and 'substance' (Ambedkar, 2014a. p. 10) of religion when derived from a deeper 'principal' (Ambedkar, 2014a, p. 10) rather than a derivative manifestation, or what is not core to the essence of something but only 'incidental' (Ambedkar, 2014a, p. 10) and apparitional. These distinctions are so pivotal. They have a tendency to differ and delay any simple meaning that can be deduced or discovered when we think of metaphysical categories of 'origin' and 'source' and 'substance.' ${ }^{11}$ Ambedkar is going after the 'principal' (Ambedkar, 2014a, p. 10) and not the phenomenal manifestation of early religions' most salient attributes - namely 'magic, totem' and their associated 'rites, ceremonies' (Ambedkar, 2014a, p. 10). For the 'principal' becomes a weapon so to speak of a powerful theoretical critique. The aim is to reveal the uncanny. What happens when a system of religion is propelled by an internal driver that justifies the real reason for a religion's existence, namely a sadistic fetish to humiliate other human beings openly and publicly? Ambedkar has yet to get to that outcome of the analysis in the "Philosophy of Hinduism," but the purpose of the commentary is to see how these earlier moments in the text foreshadow the indictment to come. How can consciousness of this public evisceration of basic human dignity become a transcendental norm for consciousness to surpass itself: that is when rites and rituals drenched in a fetishistic frenzy of seemingly paranormal proportions occlude the reality of daily oppression of labor? The more sacred the wisdom that is manifest in the tiniest of ritualistic practices, the more justified a horrific distancing of pure and impure human beings become. Twice-over, oppression is inverted; first it passes itself as the duty to obey caste function, and then through a bizarre inversion makes the public display of the oppression a daily norm, i.e. the average treatment of Dalit laborer in public amidst higher castes. A theory of the public nature of ritual debasement of humans in relation to the transcendental consciousness of false supra-human meditation is required here. The problem worsens with the metaphysical linkage with actual biological events of life, such as birth, maturation, and death, that literally brings alive the living hell of a system of human organization founded primordially on inequality and intentional mortification. ${ }^{12}$ The processes of dehumanization have their own perverse logic,

${ }^{11}$ This is what Derrida's deconstruction illustrates (Derrida, 1974).

${ }^{12} \mathrm{Again}$, it is tempting to look at the theoretical innovations in philosophy and the social sciences, particularly anthropology and sociology, in twentieth- century European intellectual history. But leveraging the tools of critical theory to dismantle false assumptions about the superiority of modern civilization (which Marx, Nietzsche, and Freud submitted to a virulent internal critique) falls short for a variety complex reasons. The Western gaze remains myopic: one must work within the lifelong oppression of caste like Ambedkar to develop a truly subaltern consciousness. Taking a non-violent and sanguine view that in fact the 'primitive' could have more complexity than an 'advanced' modern mind is willing to admit: indeed that is new type of neocolonial superiority intrinsic to the Western anthropological view, which itself has already accepted the self-critique of the West. Many today from the non-West and racial minorities within the white 
which has to be deciphered through critical theory and philosophical deconstruction. In this conflation at the heart of 'savagery' one can say are the elemental forms that would eventually be used to build divisions of laborers (caste) within a division of commodified labor (class). But we move to fast. Let us take a few steps back and return to the Ambedkar passage. There is so much to unpack there before we have a remote chance to move on in this all-important section in Ambedkar's manuscript of the "Philosophy of Hinduism."13

gentile majority West are calling for the decolonization of Western anthropological science; the latter was born in the late nineteenth century during the peak of European colonial empires. But truth be told; the West had already begun its own self-critique in the twentieth century. This is the spirit of critical thought that pervades intellectual movements such as structuralism. Lévi-Strauss's The Savage Mind (1964) and Totemism (1962) can consume an entire study in that regard. It would appear at this juncture in our commentary on Ambedkar that it is now virtually impossible to ignore Lévi-Strauss's incredibly, inventive formulations. Structuralism against dialectics (the movement of oppositions synthesizing themselves and differentiating themselves again ceaselessly) is not a simple matter. One cannot easily dismiss these debates of structuralism vs. dialectics, particularly when comparing and connecting across so many differences and relations. For example, as much as Lévi-Strauss searches for how "homology," or connection of how two systems of difference (that can never be collapsed into each other), occurs (Lévi-Strauss, 1964, p. 115), he still maintains complex differentiated relations within relations. For example, totemism as human relation to animal is distinguished from caste as 'endogamous' (Lévi-Strauss, 1964, p. 115) stratification of society with differentiated roles for different groups that appear natural. And both phenomena map differently in their own internal organizations regarding the differences and relations between the terms of 'culture' and 'nature' (Lévi-Strauss, 1964, p. 124). Yet as we shall in continuing our commentary, even these formulations cannot be applied to understand Hindu caste, let alone forge the theoretical tools to destroy it. Nature and culture do not dissolve into their dialectical opposites; they become entirely other to any Western etymology and topology. Taking theoretical concepts out of their Western contexts of invention, even Lévi-Strauss on 'primitive' or non-Western systems, and plunging right into the universe of Hinduism is no easy task. For Lévi-Strauss, connections and relations in the systems of difference that do not collapse into a synthesized whole can be continuously analyzed and broken down into ever finer distinctions, inversions, and reciprocal substitutions. The endeavor is endless. Having said all this, we will have to do a whole study of "Totem and Caste" in Lévi-Strauss's The Savage Mind (1964) and Ambedkar's critique of the philosophy of Hinduism as the social basis of caste.

${ }^{13}$ To recapitulate the manuscript offered in volume 3 of the collected writings is roughly ninetytwo pages long. Embarrassingly, the author of this commentary (through a series of articles of which this is the third part) is still only on page 10. This section in the manuscript of the "Philosophy of Hinduism," which is the first one-fourth of the whole text, is what Ambedkar calls, ironically, a long and necessary 'detour' (Ambedkar, 2014a, p. 22). In other words, Ambedkar saw the need for an extended philosophical grounding of the possibility of his own investigation into the "Philosophy of Hinduism" before getting into the actual texts and concepts of Hinduism, for example the Manu law codes that consecrate the onerous system of caste. It is our firm belief that we traverse this section slowly, methodically, and painstakingly. We must spend this much time with each paragraph, sometimes a phrase or sentence, in Ambedkar's manuscript: for our aim is to develop new philosophical tools to unpack the mysteries of caste for the purpose of its ultimate annulment in Indian society. This requires leveraging philosophical theories, particularly from the twentieth-century continental European tradition (especially German and French philosophy) to which Ambedkar did not reference or appropriate. Therein lies the justification for our slow moving, prodding textual exegesis, which is part of the heritage of critical theory, phenomenology, structuralism, and deconstruction. 
The 'principal, source, origin, and substance' are not 'magic-taboo or fetish-totem,' 'practice and worship' (Ambedkar, 2014a, p. 10). Those are 'incidental' (Ambedkar, 2014a, p. 10). Nor are the occasions of life construed as 'crises' known as 'birth, death, maturation, sickness, war, death' (Ambedkar, 2014a, p. 10), at least not entirely. Now Ambedkar is going for the actual motor force - the 'preservation of life' (Ambedkar, 2014a, p. 10) and the madness involved in a preservation at all costs, which means the means can justify the end. Caste - as segmented and segregated spatialization of human beings in compartments for which the only entrance is birth and only exit is death - is like one large metaphysical panopticon that hierarchizes and views all of society in a glance. ${ }^{14}$ The supervision functions to guarantee the omnitemporal plane of transmigration of souls, which then gets telescoped down to the microscopic activity of daily life within the caste system. The mystery is how this is linked to the fundamental 'principal' that marries 'preservation of life' with avoidance of 'evil' and 'harm' (Ambedkar, 2014a, p. 10). This is a prior distinction before we get to purity-good and impurity-demonic distinctions, around which the entire social system is organized. To think this hinges strictly on the biological truth of the survival of the species is merely superficial.

Turning back to the passage, this is what we find. All philosophies and religions across space and time have tried to excavate the mysteries of 'human existence such as life, death, and birth' (Ambedkar, 2014a, p. 10). Anthropologists add in rites such as passage into adulthood, marriage, and funerals, among other major life transitions and events. However, the quest for the principal (before any good and evil distinction emerges) cannot be divorced from the 'principal' substance of religion as concerned with the vagaries of life on earth, why we are born and have to die. Before attempting to describe how rites and rituals of 'magic, tabu, totem, and fetish' (Ambedkar, 2014a, p. 10) function and what they mean, one needs to start with a prior clearing of assumptions. Ambedkar says those elements are merely the 'means' to a larger 'end' (Ambedkar, 2014a, p. 10). If they are not the end but only the means, then this raises the question of what constitutes the end for which religion was born and upon which it stands.

Ambedkar tells us, in an unsurprising way, that the "end is life and the preservation of life" (Ambedkar, 2014a, p. 10). This seems totally intuitive. All of evolution of life points to the propagation and preservation of life even as life evolves in new directions; life has to change to adapt to changing environments or it will disappear; and in fact some species do disappear. The teleological purpose of our life-supporting planet is to extend life, not to terminate it. (Human actions like the creation of climate

${ }^{14} \mathrm{We}$ have always longed for a full investigation in to all of Foucault's corpus, the early works on madness, medicine, and the organization of the social and natural sciences, to the later works on prisons/discipline, sexuality, biopower, governmentality, security, and population management. A Foucaultian analysis of caste by way of an appropriation of concepts in Discipline and Punish: The Birth of the Prison (Foucault, 1977) would be necessary. But that means certain concepts like "disciplinary technology" (Foucault, 1977, p. 227) of power and "microphysics of power" (Foucault, 1977, p. 28) would have to be reformulated so they have greater purchase in understanding phenomena in postcolonial Global South development contexts, not the long duration of Western history and society. Foucault, of course, only knew of the latter. 
change is another matter.) All of this makes sense and is always an oceanic source of joy and appreciation that in fact life did start on earth and those living now are the beneficiaries of this rare occurrence in the physical universe. The more we step back and see of all humanity (over eight billion people on the planet), the more in awe we are of this beautiful mystery. Obviously anything that brings 'harm to life' or 'exercise evil influences' (Ambedkar, 2014a, p. 10) must be guarded against. Anything that would destroy life is tantamount to evil. ${ }^{15}$ We quote the second half of the passage again:

Thus understood the religion of the savage society was concerned with life and the preservation of life and it is these life processes which constitute the substance and source of the religion of the savage society. So great was the concern of the savage society for life and the preservation of life that it made them the basis of its religion. So central were the life processes in the religion of the savage society that everything which affected them became part of its religion (Ambedkar, 2014a, p. 10).

The process of life and its preservation form the main purpose. Life and preservation of life is the core and centre of the Religion of the savage society (Ambedkar, 2014a, p. 10).

Isolating the fundamental terms of the passage, namely "savage society" (Ambedkar, 2014a, p. 10), if one were to avoid judgement of what 'savage' here means, is actually quite remarkable, even from a modern standpoint. Our laws and most states, other than the very few that commit genocide on its own people or so oppress them to the point of oblivion, have as their goal the security, sustenance, and development of its people; in democracies that includes liberty, in non-democracies that means collective submission to larger social ideals. States exist to protect people from inhibiting themselves from achieving these goals.

But upon closer scrutiny about the 'religion of savage society' as 'concerned with life and preservation of life' (Ambedkar, 2014a, p. 10), we begin to see the beginnings of what will be a powerful critique made by Ambedkar in his judgement of Hinduism as a religion. We already know from him that this most ancient of extant religions is not founded on 'justice and utility' (Ambedkar, 2014a, p. 22). We now have to examine the nature of this 'concern' for the 'preservation of life' and how 'life processes' have come to constitute the 'substance and source of religion of 'savage society' (Ambedkar, 2014a, p. 10). We repeat these terms because they are so profound in their meaning when it comes to the philosophy of religion. Life for life's sake or the will to live do not penetrate the depths of philosophical understanding in that regard. Any utilitarian logic to increase pleasure and minimize pain is only scratching the surface of the matter.

For the critical investigator of the philosophical and religious origins of caste, we are struck immediately with a series of aporias and paradoxes. How does the 'concern' for the 'preservation' of life as the 'basis' and 'core' of religion [not the 'incidental

${ }^{15} \mathrm{We}$ can compare and contrast with the Abrahamic, monotheistic faiths of Judaism, Christianity, and Islam all of which point to the divine origin of life and the sacred nature of human life itself. 
means' of 'magic, tabu, totem, and fetish' (Ambedkar, 2014a, p. 10)] become perverted into a logic of discipline and desire to humiliate, degrade, and ultimately vanquish any ounce of dignity in what it means to be a human being? This would mean that the great concern for life became fused with the great demoralization of life; the increase of one, leads to the increase of the other. There is no transcendence of biological finitude, or physical death. And so the anxiety around the approach to death is turned backwards to birth, the beginning of life, which must be controlled throughout. Birth is emptied of any value as a unique, one-time, irreproducible event. Guarding the passages from death to birth, which is a rebirth, and the passage of birth to death to the threshold of another rebirth point two arrows of time neither of which flow in a linear or circular manner. The two poles of 'birth' and 'death' do not lead to a stretch of life in-between called an individual; they are crossed out, what is other to birth is the passage from death to rebirth and what is other to death is the conquest of its grip and a loosening of its finality.

As we shall see, the entire architecture of these fundamental problems of being, time, birth, and death must be contrasted with the Western philosophical tradition. ${ }^{16}$ The 'basis, center, core, source, substance, and origin' of religion is motivated by the 'concern for the preservation of life (Ambedkar, 2014a, p. 10). The central question for Ambedkar in his text is why did this 'savage' (Ambedkar, 2014a, p. 10) system not undergo a revolution in the concept and nature of religion; and because of this delay or postponement of radical change in the nature of everything, a perversion took root, a degeneration of which the consequences would be enormous.

When the obsession about life-preservation at all costs loses consciousness of the reason and intention of why life must be preserved no matter what, so that life for life's sake becomes an unquestionable dictum, then that is one thing. The automation of life is the automation of the will to live. However, when it is glued to the material domain of rites, rituals, taboos, and beliefs to ward off 'evil' and 'harm' (Ambedkar, 2014a, p. 10) that is yet another development. However, when a metaphysical architecture of what life means, inclusive of its origin (arche) and end (telos) but crossing out of those poles (physical birth and physical death) in the concept of reincarnation, is melted with extreme concern and anxiety for life, then a whole new order of society is born. But that means the society, which should have been created out of the origin of religion based on the 'concern for the preservation of life' (Ambedkar, 2014a, p. 10), yields a monstrous other. And the worse form of a social contract is born; in fact it is an anti-social contract.

\footnotetext{
${ }^{16}$ What we must investigate will be in total contrast to everything Heidegger says in Being and Time, particularly in section 72 of Chapter V of Division Two on "being-towards-the beginning" and "being-towards-death," " "connectedness of life,", how existence "stretches along between birth and death," and the "sequence of Experiences "in time"" (Heidegger, 1962, p. 425) all point to complex problems of life, time, and movement, about which the Western philosophical traditions have anguished. From the Pre-Socratics in ancient Greece to Hegel to Heidegger, no definitive answers have been found. Heidegger himself tried to destroy all previous metaphysical conceptions by calling into question linear time and spatialized motion, even the idea of being in time (Heidegger, 1962, p. 436). Faith-based religions, like Christianity, may try to provide answers, and theology serves the purpose of providing a philosophical rationality for otherwise unprovable, even irrational notions, such as an 'afterlife' or 'heaven'; but that does not mean philosophical logic independent of religious subjectivity has come to any definitive answers.
} 
One can say the creation of Indian society founded on caste involves the erasure or aborting of another birth that should have happened. A historical reincarnation becomes self-fulfilling in an inverted way when a new birth does not replace death, but one birth replaces a birth that did not happen but should have happened. If the traditional notion of reincarnation is the movement from death to another birth, then here we speak of a reversal, when one birth prevents another from happening. Could this be the secret logic of the caste system?

Staving off 'evil' and preventing 'harm' (Ambedkar, 2014a, p. 10) through segregated rites and rituals for the salvation of an elite few (the Brahmins) through a constituted Other as permanently impure, namely the Dalits, may be a weird curiosity for outsiders who try to visit and see Indian society for the first time. But then the hierarchical ladder of worth - of higher castes descending to less worthy lower ones in between the highest (Brahmin) and the lowest (Dalit) - constitute a whole that we must investigate following the reflections of Ambedkar. Trying to justify the destiny of certain births to an abhorrent life of labor means the Hindu apotheosis and celebration of futility: namely the inability to transcend class and function but also essentialized identity (Dalit must equal demonic impurity) too forms a nightmare of proportions we are barely able to fathom. The perpetual sacrifice of dignity is the only guarantee for the preservation of life. This falls so far below the threshold of the moral basis of a human right (Shue, 1980) that one can no longer speak of human beings. We are just a few steps away from the next major plateau in Ambedkar's analysis, which we can foreshadow here in our conclusion.

\section{Conclusion}

By tracing the movement of Ambedkar's thought from the unsubstantial surface of 'magic, totem, tabu, and fetish' (Ambedkar, 2014a, p. 10) we arrived to the 'substance' itself, the 'core and center of the Religion of savage society' founded on the 'preservation of life' (Ambedkar, 2014a, p. 10). What seems like a remarkable quality of 'savage' society, namely the 'preservation of life' (Ambedkar, 2014a, p. 10), will be at the end something extremely deleterious when the social structure of caste finally emerges. In terms of ideological dissimulation, the rites, rituals, and ceremonies, which are embodied in the practices of 'magic, totem, tabu, and fetish' (Ambedkar, 2014a, p. 10), seem to constitute the essence of religion. But for Ambedkar they are not. The real problem is that 'savage' society construes the basic events of life's journey, birth, sickness, and death as 'crises' (Ambedkar, 2014a, p. 10). The key point is at this early stage, 'birth' is considered a crisis. How this prepares the conditions for theological reflection in Hindu metaphysics on birth, death, and rebirth becomes an open question for philosophical speculation.

Before Ambedkar can engage the actual contents of Hinduism's main texts, the Upanishads, the Epics, and the Manu law codes, he must pass through another set of reflections on the philosophy and sociology of religion. He will return to the earlier consideration we saw in Part II of commentary on the relations of society, God, and man (Ambedkar, 2014a, p. 9); but this time he will introduce a series of fissures that 
links what he calls the transition, or rather philosophical revolution, from the religion of 'savage' society to the religion of 'civilized society' even though there is an initial similarity between them (Ambedkar, 2014a, p. 11), namely the need to preserve life.

But then a fissure takes place whereby morality is detached from religion in 'savage' society (Ambedkar, 2014a, p. 12). This occurs when the Idea of God is born paving the way for the religion of 'civilized' society (Ambedkar, 2014a, p. 12); the latter marks a stupendous event where concern for the well-being of human dignity is primary, not the ceaseless drive to reproduce life whose mysteries are guarded by supernatural ritual. This event of the divorce of morality and religion requires a genealogical analysis, which cannot be a replica of any Western analysis of a similar divorce in its context. ${ }^{17}$ In traditional Western metaphysics and its Judeo-Christian roots, God may be considered the Origin or Cause of the Creation; but in this Eastern context, we have submerge into the darkness and abyss that constitutes the 'origin' of God.

We decided to pause this part of our commentary here. To traverse what follows next in Ambedkar's sweeping narrative on the philosophy and history of religion, we had to take these necessary steps. In part IV of the commentary, we will make our deep dive into Ambedkar's examination of morality, the idea of God, and even the origin of the idea of God (Ambedkar, 2014a, p. 12). This will take us into a speculative philosophical realm; not for the purpose of an unnecessary and abstract metaphysics but because the heuristic reason is established to set the stage for a massive philosophical critique of Hinduism. Through Ambedkar, we will discover the failure of two revolutions spread out in historical time, namely the lack of transition from 'savage' to 'civilized,' and then within 'civilized', the demarcation of 'ancient' and modern' (Ambedkar, 2014a, pp. 12-13). The implications for our philosophical understanding of a different idea of historical time are immense; to truly understand how Hinduism might have emerged as a justification of the unequal and inhuman system of caste means we must disentangle ideas of 'savage' and 'civilized' and 'ancient' and 'modern' from their traditional senses. All of them begin to combine and mutate in strange ways. This means that in the very ground and conditions for the emergence of caste is something uncanny: it has everything to do with how we appropriate the legacy of Ambedkar in reconceiving the task of a philosophical critique of religion by way of a theoretically rigorous analysis of historical revolutions.

\section{References}

Ambedkar, B.R. (2014a). Dr. Babasaheb Ambedkar: writings and speeches, vol. 3. In Narake, Hari (Ed.), $2^{\text {nd }}$ edition, New Delhi: Dr Ambedkar Foundation.

- (2014b). Annihilation of caste. In S. Anand (Ed.), London: Verso Press.

Derrida, Jacques. (1974). Of grammatology (trans. Gayatri Spivak). Baltimore: Johns Hopkins University Press.

Foucault, Michel. (1977). Discipline and punish: the birth of the prison (trans. Alan Sheridan). New York: Vintage Books.

${ }^{17}$ For example, Nietzsche's On the Genealogy of Morals of 1887. 
Hegel, G.W.F. (1977). Phenomenology of spirit (trans. A.V. Miller). Oxford: Oxford University Press.

Heidegger, Martin. (1962). Being and time (trans. John McQuarrie and Edward Robinson). New York: Harper and Row.

Lévi-Strauss, Claude. (1966). The savage mind. London: George Weidenfeld and Nicholson Ltd.

Marx, Karl. (2015). Capital, Vol. 1. (trans. Samuel Moore and Edward Aveling). Moscow: Progress Publishers, Moscow, USSR.

Nietzsche, Friedrich. (2007). On the genealogy of morals (trans. Carol Diethe). Cambridge: Cambridge University press.

Shue, Henry. (1980). Basic rights. Princeton: Princeton University Press. 